\title{
Hybrid perspectives: Muslim and secular discourses in French politics
}

\author{
Aprillia Firmonasari \\ Universitas Gadjah Mada, Indonesia \\ E-mail:aprillia@ugm.ac.id \\ Wening Udasmoro \\ Universitas Gadjah Mada, Indonesia \\ E-mail:udasmoro@ugm.ac.id \\ Roberta Salzano \\ Università l'Orientale, Napoli-Italia \\ E-mail: salzano.roberta@gmail.com \\ DOI:10.18326/ijims.v11i2.299-325
}

\begin{abstract}
Increased immigration, especially from Muslim-majority countries, has been broadly debated in French socio-political life. Frictions have been common between two groups: Muslims and non-Muslims who identify themselves as 'defenders of secularism.' At the same time, however, hybrid strategies have emerged in which Muslims and non-Muslims have sought to culturally and socially adapt themselves. Through a review of online French media published between 2017 and 2020, as understood using social constructivism, this study explores the groups' construction of hybrid identities. Discourses were analyzed
\end{abstract}


to identify their ideological schemes, utterances, references, and arguments, with linguistic analysis facilitated by NVIVO software. Analysis shows that the hybrid discourses of non-Muslim 'defenders of secularism' have been more prominent than those of Muslims. Furthermore, the narrative tendencies of these hybrid discourses indicate that non-Muslim groups have sought to promote diversity in religious practices in France, while Muslim groups have sought to integrate themselves into broader French society.

Meningkatnya jumlah imigran, terutama imigran muslim menjadi persoalan sendiri pada kehidupan sosial politik Prancis. Seringkali terjadi gesekan-gesekan narasi mengenai keislaman antara dua kelompok, yaitu kelompok muslim; dan non-muslim yang melabelkan dirinya sebagai 'pembela sekularitas'. Namun di sisi lain, muncul pula narasi hibrid yang memuat strategi adaptasi budaya dan sosial dari kelompok muslim maupun kelompok non-muslim. Maka dari itu, penelitian ini membahas konstruksi wacana hibrid pada dua kelompok tersebut di media online Prancis dari tahun 2017 sampai 2020 dengan menggunakan perspektif konstruktivitis sosial dalam masyarakat menurut Lev Vygostky. Data wacana dianalisis dengan skema ideologis, tuturan, referensial dan argumentasi dengan melihat konteks wacana dengan menggunakan alat bantu linguistik NVIVO. Hasil analisis menunjukkan bahwa wacana hibrid dari kelompok non-muslim 'pembela sekularisme' lebih tinggi daripada wacana hibrid dari kelompok muslim. Selain itu, pola-pola narasi konstruksi wacana hibrid menunjukkan bahwa kelompok kelompok non-muslim bersikap terbuka dengan adanya keberagaman agama dan praktik keagamaan di negara Prancis; dan kelompok muslim berkeinginan untuk dapat berintegrasi dengan masyarakat Prancis.

Keywords: Muslims; Non-Muslims; Constructivism; Hybridity; Secularism 


\section{Introduction}

The question of Islam in France is not merely an ideological one, but also a political one. In other words, Islam occupies a dualistic position in French society. Most of the people of France-especially radical republicans-view Islam as incompatible with the French culture and ideology, including the concept of laicité ('secularism') and guarantees the separation of Church and State. ${ }^{1}$ At the same time, however, many in France (particularly those who have embraced pluralistic liberalism) see Islam as having become incorporated into French culture with the increased Muslim population, driven predominantly by widespread migration from the Maghreb since the 1960s. The Muslim diaspora, members of which come predominantly from western and northern Africa, have spread throughout France. ${ }^{2}$ France is a country with the biggest Muslim population in Europe. In 2020, it was identified that there are 5.430.000 Muslims living in France while 37.940.000 were Christian.

Today, the media offers an effective means of conveying political and religious narratives. This is true not only in France, but also in Indonesia, the world's largest Muslim-majority country. The Muslim organization Muhammadiyah established TVMU (Muhammadiyah Television) to promote its proselytisation activities and disseminate its perspectives ${ }^{3}$.

\footnotetext{
${ }^{1}$ Aprillia Firmonasari, Wening Udasmoro, and Yohanes Tri Mastoyo, "Understanding Secularism and National Identity in French Political Discourses," Humaniora Vol. 32, no. 2 (2020), 135-50; Philippe Portier, "The Substantivist Turn of French Laicism," Horizontes Antropológicos, Vol. 24, no. 52 (2018), 21-40.

${ }^{2}$ Christopher Allen, Islamophobia, Burlington: Ashgate, 2010; Wening Udasmoro, "The Language Construction of Muslims as The Others in French Contemporary Discourses," Indonesian Journal of Islam and Muslim Societies, Vol. 7, no. 1 (2017): 77-99.

${ }^{3}$ Wahyudi Akmaliah, "The Demise of Moderate Islam: New Media, Contestation, and Reclaiming Religious Authorities," Indonesian Journal of Islam and Muslim Societies, Vol. 10, no. 1 (2020): 1-24.in which they do not engage a lot of this development of the digital platform. Consequently, dealing with religious issues, their voices become voiceless. By employing desk research through some relevant references and collecting information from social media, specifically Instagram and Youtube, this article examines the role of the Islamic organization of moderate Islam in the rapid of the digital platform as the new of the public
} 
Meanwhile, the 'Action to Defend Islam' (Aksi Bela Islam), a popular movement protesting the perceived blasphemy of Jakarta Governor Basuki Tjahaya Purnama, emerged from social media: Facebook, Twitter, and Instagram. These examples, as well as similar phenomena, show that Islamic identities can be asserted and even created through mass and social media. ${ }^{4}$

In France, increased immigration from Muslim-majority countries has significantly influenced politicians' narratives and discourses in the media. Even though France has long identified itself as a laique, or secular, state, wherein religious sentiments have been abandoned, discourses have continued to emphasize 'Christian identities' and 'Christian heritages' (vis-à-vis Islamic ones) as part of French identity. This has frequently resulted in the marginalization of Islam and Muslims in France. ${ }^{5}$ At the same time, Christian discourses have sought to validate the secular values that underpin the 'essence of Europeanness,' while simultaneously positioning Islam as opposed to these values. ${ }^{6}$ This may be traced back to the Crusades, centuries of Christian-Muslim warfare that have left a deep trauma in the French psyche. Islam has been deemed incompatible with a "European" mindset, prone to fundamentalism and radicalism, and replete with a culture of backwardness. ${ }^{7}$ At the same time, however, new narratives have

sphere. The article finds that they have difference respond to dealing with the presence of the new religious authorities. In comparison, while Muhammadiyah is more accepting of them calmly, NU is more reactively in responding.Lanskap ruang publik Indonesia di tengah muncunya media sosial membuka kesempatan sekaligus ancaman terkait dengan dakwah Islam. Hal itu merupakan ancaman bagi dua organisasi besar Moderat Islam di Indonesia (Muhammadiyah dan NU

${ }^{4}$ Muzayyin Ahyar and Alfitri Alfitri, "Aksi Bela Islam: Islamic Clicktivism and the New Authority of Religious Propaganda in the Millennial Age in Indonesia," Indonesian Journal of Islam and Muslim Societies, Vol. 9, no. 1 (2019): 1-29.

${ }^{5}$ Wening Udasmoro, "Discourse Subaltern Dalam Masyarakat Interkultural: Mencermati Relasi Gender Jilbab Dan Perempuan Berjilbab Di Prancis”, Jurnal Ilmu Sosial Dan Ilmu Politik, Vol. 14, no. 1 (2010), 1-22.

${ }^{6} J a m e s$ McDougall, "Laïcité, Sociologie et Histoire Contemporaine de l'islam," Annales, Histoire, Sciences Sociales, Vol. 73, no. 2 (2018), 411-39.

${ }^{7}$ Giulia Evolvi, "Hybrid Muslim Identities in Digital Space: The Italian Blog Yalla”, Social Compass, Vol. 64, no. 2 (2017), 220-32. 
emerged promoting a hybridity wherein Muslims adapt socially and culturally to laïcité while also receiving space for their own discourses. ${ }^{8}$

The media, through which these hybrid narratives are presented, has employed two perspectives to construct discourses of Islam and secularism: those who identify themselves as Christians and those who identify themselves as Muslims. The online publication la Croix, for instance, published a statement by the Cardinal of Lyon that condemned the concept of secularism and nationalism advocated by the openly anti-immigrant Front National, which he believed would bring naught but disaster to the French people. In a joint statement with Apostolic, Orthodox, and Anglican leaders, the Cardinal emphasized that diversity would not result in fragmentation, but would rather promote sharing, debate, and exchange. Furthermore, they argued that the views of the Front National were not reflective of Christianity, which seeks the eradication of discrimination, inequality, hatred, and xenophobia. The same opinion was raised by Benoit Hamon (politician from Socialist party with centre-left wing ideology). According to him, secularism was a "shield" to reunite French people. He also urged to stop all kinds of accusations saying that Muslims were the core of all of the problems. Another statement was also raised by Jean-François Bayard, a sociological historian, who stated that laïcité est une nouvelle religion nationale (secularism is a new national religion), which means that all practices of religions in France referred to laicite law created in 1905.

Muslim groups, similarly, have created a hybrid discourse. In an interview with publicsenat.fr, Mohamed Bajrafil-an imam, theolog, and linguist-stated that it was 'normal for non-Muslims in France to ask about Islam.' He explained that the Islam in France is one with diverse ideologies. Discussion of Islam in France, thus, must consider the various French institutions involved in the integration process, including those institutions that teach

\footnotetext{
${ }^{8}$ Giulia Evolvi, "Hybrid Muslim Identities...
} 
imams about French culture, language, and social reality. As such, Mohamed Bajrafil concludes that the Muslims living in France should vivre à la fois sa francité et son islamité 'live simultaneously in their Frenchness and their Islamness.' The same opinion was also stated by Mohammed Moussaoui, the president of Conseil Français du Culte Musulman - CFCM, (The French Council of Muslim Worship (an association under the Ministry of Internal Affairs that represents French Muslims vis-a-vis the State related to the practice and activities of Islam). He argued that secularism was not a denial against the practice of religion. Moussaoui added that Islam is only one but it has different expressions and contexts that play important roles in the religious practices. As a consequence, Muslims in France have to adapt their practice with the cultural dominant context.

From these statements, a duality is evident in the hybrid discourses of Islam and secular France. On the one hand, Christian groups have contributed to diversity by offering equality to all individuals in France, irrespective of their religious beliefs. On the other hand, Muslim groups have promoted integration and acculturation amongst immigrants, particularly Muslim ones. It is hoped that, through integration, friction can be reduced, and all elements of French society will understand their specific positions and the freedom to practice their own religions and beliefs.

To date, studies of Islam vis-à-vis laicité have tended to view Islam as being marginalized, or otherwise framed it as not occupying a safe position within French society. French Muslims are depicted as lacking access to mass media, and as such lacking the capacity to challenge their own inequality 9 . As explained by Jennifer Fredette in his book Constructing

${ }^{9}$ Jennifer Fredette, Constructing Muslims in France - Discourse, Public Identity, and the Politics of Citizenship, Philadelphia: Temple University Press, 2014.exclusions, and hierarchies it claims to deplore as Muslims face discrimination in education, housing, and employment. In Constructing Muslims in France, Jennifer Fredette provides a deft empirical analysis to show the political diversity and complicated identity politics of this relatively new population. 
Muslims in French: Discourse, Public Identity, and the Politics of Citizenship, Muslim identities are being continually negotiated and re-negotiated in modern-day France. Meanwhile, political elites have tended to employ four perspectives, three of which exclude Muslims (ethno-centric, critical, and conservative) and one that embraces Muslims and immigrants (predominantly embraced by leftist groups). Even then, however, those with "open" paradigms have experienced fragmentation, as many have been disappointed by ongoing socio-political issues. ${ }^{10}$

Although Article 1 of the French constitution holds that France "shall ensure the equality of all citizens before the law, without distinction of origin, race or religion," injustice is still commonly faced by Muslims and other minorities. ${ }^{11}$

She examines the public identity of French Muslims and evaluates images in popular media to show how stereotyped notions of racial and religious differences pervade French public discourse. $\backslash \mathrm{n} \backslash \mathrm{n}$ While rights may be a sine qua non for fighting legal and political inequality, Fredette shows that additional tools such as media access are needed to combat social inequality, particularly when it comes in the form of unfavorable discursive frames and public disrespect. $\backslash \mathrm{n} \backslash \mathrm{nPresenting} \mathrm{the} \mathrm{conflicting} \mathrm{views} \mathrm{of} \mathrm{French} \mathrm{national} \mathrm{identity,} \mathrm{Fredette} \mathrm{shows}$ how Muslims strive to gain recognition of their diverse views and backgrounds and find full equality as French citizens. \n \nThis title was made Open Access by libraries from around the world through Knowledge Unlatched.","ISBN":"978-1-4399-1029-0","language":"English", "note":"Accepted: 2018-06-27 23:55 \nDOI: 10.26530/OAPEN_469365","publisher":"Temple University Press","source":"library.oapen.org","title":"Constructing Muslims in France Discourse, Public Identity, and the Politics of Citizenship","URL":"https://library.oapen. org/handle/20.500.12657/33466","author":[\{“family":”Fredette","given”:”Jennifer”]],"acc essed”:\{“date-parts”:[[“2020”,11,14]]\},"issued”:\{“date-parts”:[[“2014”]]\}\}],"schema”:”https:// github.com/citation-style-language/schema/raw/master/csl-citation.json”\}

${ }^{10}$ Hasnul Insani Djohar, "Folktales and Rites of Passage in Randa Jarrar's A Map of Home", Poetika: Jurnal Ilmu Sastra, Vol. 7, No. 2 (2019), 148-57.

${ }^{11}$ Abderrahim Ait Abdeslam, "The Representation of Islam and Muslims in French Print Media Discourse: Le Monde and Le Figaro as Case Studies”, Journal of Muslim Minority Affairs, Vol. 39, No. 4 (2019), 569-81.due to many attacks that have hit France, and which are allegedly attributed to Muslims, this minority suffers vilification and discrimination. However, Muslims should be treated and reported fairly in France as the Article One of the French Constitution declares that "it [France] shall ensure the equality of all citizens before the law, without distinction of origin, race, or religion”. This signifies that French institutions, especially the media, should apply the article above and try to present a fair image of its citizens including Muslims. Media, in this regard, are at play in their representation of this minority of French citizens. Nevertheless, most Western media rely on the Orientalist views to report 
As France identifies itself as a democratic country that embraces the concept of égalité 'equality', individuals should receive equal rights and obligations. French media, similarly, should emphasize equality in its coverage even as it remains neutral. In reality, however, a study by Abderrahim Ait Abdeslam found that most French media outlets continue to employ an orientalist perspective in their coverage of Muslims and Islam. In other words, Muslims continue to be excluded from the French 'Self' in French media discourses.

The aforementioned narratives of hybridity may be understood through a social constructivist perspective. According to Vygotsky, ${ }^{12}$ knowledge is constructed socially, and communication is the social process through which reality is created. It is not a cognitive epistemology, as common in constructivism, but rather one wherein psychological construct such as 'thought,' 'self,' and 'emotion' are constructed through social discourses. Knowledge is not something possessed by individuals and confined within their minds; rather, it is constructed collectively ${ }^{13}$. In other words, the hybrid discourses mentioned above are produced, expressed, and inexorably related to individuals' knowledge and internalization of cultural and social norms and practices.

Recognizing that the social construction of identity does not exist in a vacuum, but rather occurs through relational processes, this article explores the discursive positioning of Self and Other as a means of ensuring the conduciveness of political life ${ }^{14}$. As such, it emphasizes the element of

Muslims and Islam (Edward Said, Orientalism, New York: Vintage, 1977

${ }^{12}$ L.S. Vigotsky, "Interaction between Learning and Development", in L.S. Vigotsky, Mind in Society: Development of Higher Psychological Processes, Cambridge: Harvard University Press, 1978, 79-91.

${ }^{13}$ Katarina A Rodina, "Vygotsky”s Social Constructionist View on Disability: A Methodology for Inclusive Education," in Enabling Lifelong Learning in Education, Training and Development: European Learning Styles Information Network (ELSIN), Oslo CD/ISDN: University of Oslo, 2006), 27.

${ }^{14}$ Ayu Fitri Kusumaningrum, "Krisis Identitas Dalam Cerpen A Pair of Jeans Karya Qaisra Shahraz," Poetika : Jurnal Ilmu Sastra, Vol. 7, no. 1 (2019), 51-62. 
inclusion. In other words, it seeks to understand how secular groups have viewed French Muslims as well as how French Muslims have viewed the French ideal of laïcité (secularism). In doing so, it hopes to identify the patterns of social inclusion that are developed to improve social cohesion in France in the face of increased othering and exclusion.

This study analyses the hybrid discourses advanced by Muslim and secular groups in French mass media between 2017 and 2020, a period during which Muslim immigration increased rapidly. According to data from statista.fr, in 2018, 84\% of respondents blamed France's ongoing socio-political issues on immigrants-particularly Muslim immigrants ${ }^{15}$.

Data, after being collected, were classified in terms of their utterance, theme, and period, and then analyzed and discussed in terms of their meaning features. Analysis was conducted using a combination of critical discourse analysis and interactionism. It involved two stages: ideological analysis, to ascertain the ideological content and structure of discourses, and to categorize it in terms of their identities, activities, goals, norms, and social values (as related to participants, actions, interactions, and cognitive processes); and utterance analysis, in terms of references and arguments. Such analysis was used to ascertain the values and changes embodied within ${ }^{16}$.

\section{Hybrid narratives from 'defenders of secularism'}

Discussing secularism means discussing the questions of homogeneity and plurality, integration and community, individuality and collectivity, homogeneity and heterogeneity, and private and public. This study, thus, maps how Islam is narratively constructed by two groups: those opposed to Islam, who identify themselves as the 'defenders of secularism,' and Muslims

${ }^{15}$ E. Moyou, "Possibilité de débats sereins sur l'immigration selon les Français 2018," Statista, November 1, 2019.

${ }^{16}$ Rizqi Auliawati Putri, "Dekonstruksi Girl Power dalam Novel The Devil Wears Prada Karya Lauren Weisberger," Poetika : Jurnal Ilmu Sastra, Vol. 8, no. 1 (2020), 51-63. 
IJIMS: Indonesian Journal of Islam and Muslim Societies, Volume 11, Number 2, December 2021: 299-325

themselves. There are 676 data collected from the media in this research. Some of the media are affiliated with left, centre and right wing parties. Mass media content was coded using NVIVO software; the results follow below.

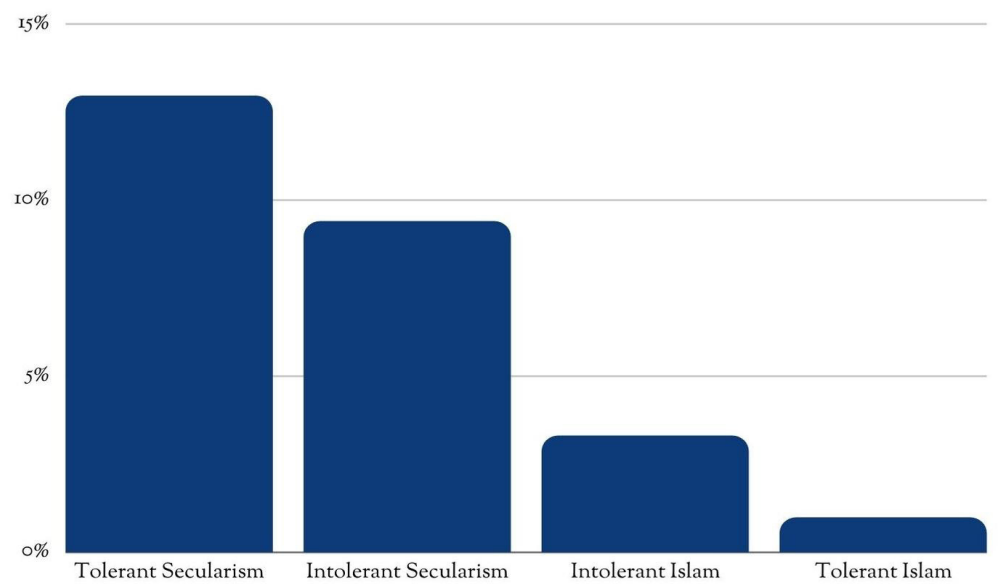

Table 1. Discourses regarding Islam conveyed in Mass Media

From Table 1, it is evident that discourses presented by self-proclaimed 'defenders of secularism' that promote tolerance (12.94\%; 127 references) were more common than those that promote intolerance $(9.38 \% ; 100$ references). Meanwhile, discourses that present Islam as compatible with French values $(0.97 \% ; 10$ references) are fewer in number than those that present Islam as intolerant (3.29\%; 31 references). This illustrates these groups' tendencies in creating hybrid discourses, as detailed below:

Geisser ${ }^{17}$ likens Christianity's view of Islam to Western capitalism's view of communism, identifying it as being framed by competition despite shared ideological roots. In their relations with Muslims, European

${ }^{17}$ Vincent Geisser, "L'islamophobie En France Au Regard Du Débat Européen," in Musulmans de France et d'Europe, Rémy Leveau and Khadija Mohsen-Finan (eds.), Connaissance Du Monde Arabe Paris: CNRS Éditions, 2013, 59-79. 
Christians have been shaped by ideological structures that have historically cultivated a fear and hatred of Islam. As such, Christians have often excluded Muslims from European society. Recently, however, there have been efforts to create dialog and to establish positive interfaith relations. Several examples of inclusivist narratives are presented below:

\section{Religious freedom within a national context}

Recognizing the increased immigration of Muslims to Europe, the French government has sought to ensure Muslims' freedom of worship. Such awareness is evident in the phrase l'Islam des caves ('Islam of the cellars'), which is commonly used to denote the fact that-owing to a lack of mosques-many Muslims have used their cellars and garages for worship. The establishment of the French Council of the Muslim Faith (Conseil Français du Culte Musulman, CFCM) in 2003 to facilitate Islamic worship has been identified as a milestone in the integration of Islamic values into the French Republic, as it has offered a liberal structure through which Muslims can integrate themselves into France's plural society. This project has been seen as conforming to the secular values of French society, and as reflecting the principle of freedom of worship that is ensconced in the Constitution of 1905.

Nonetheless, there have still been those who have sought to block such efforts in the name of defending pure secularism. As such, CFCM has sought to establish dialog and negotiate with those deemed 'opposed' to European Muslims ${ }^{18}$. Representatives of CFCM have met with numerous French politicians, including François Fillon (the former prime minister, and a leader of the Republicans, right-wing parties) on April 11, 2017. During this meeting, Fillon asserted his dedication to "an open secularism

\footnotetext{
${ }^{18}$ Pierre-Henri Prélot, "Les tentatives d'organisation du culte musulman en France au prisme du principe de laïcité," Revue du droit des religions, no. 6 (2018), 13-26.
} 
that respects the beliefs of all, including by opposing prohibitions against veiling on campus, seeking to uphold the Constitution of 1905, and challenging all deemed opposed to the laws and values of the Republic."

Such beliefs are evident in other statements by Fillon. On April 13, 2017, at the Noor-al-Islam Mosque, he stated Je suis croyant et me bat pour liberté des religions. Je suis opposé à ceux qui disent qu'il faut interdire symboles religieux dans écoles ou durcir la laïcité ("I am a man of faith, and I fight for freedom of religion. I am opposed to those who say that we must prohibit the use of religious symbols in schools or reaffirm secularism”). According to Fillon, it is inappropriate for all French Muslims to suffer because of the political activities of a fundamentalist minority. He stated that Muslims had become part of the French national community, and as such the values of liberty, democracy, and women's rights had to be upheld. In this context, it can be seen that the hybrid discourses of Islam are also inexorably linked with the public practice of religion (as regulated by French law).

\section{Religious practice under French law}

Although France has historically been a Catholic country, religious practice has become less prominent in recent decades. The percentage of French citizens attending church regularly (defined as once per month) has decreased to 7\%, from 9\% in 2008. Meanwhile, only 32\% of French people identify themselves as Catholic; $19 \%$ of them do not participate in any religious rituals. This reduced religiosity may be attributed to a generational shift, wherein a more religious older generation has given way to an irreligious younger one. Secular values have thus become dominant, such that Jean-Paul ${ }^{19}$ describes France as a "Catholic country with a secular culture" or a "secular country with a Catholic culture."

\footnotetext{
${ }^{19}$ Jean-Paul Willaime, "Religious and Secular France Between Northern and Southern Europe”, Social Compass, Vol. 45, no. 1 (1998), 155-74.
} 
The erosion of Catholic values has coincided with the rise of minority religions, particularly Islam, in the face of increased immigration. The religious landscape has thus become increasingly plural.

France's increasing Muslim population has resulted in the establishment of multiple mosques. According to the CRMF (Representative Council of French Muslims), mosques must have four functions: religious (i.e. as places for religious activities), cultural (i.e. as places for disseminating Muslim culture), intellectual (i.e. as places for studying the Qur'an), and social (i.e. as places for improving community solidarity and distributing charity). The increased number and importance of mosques evidences the rapid growth of the religion in France ${ }^{20}$. At the same time, however, many have questioned the position of religion in a free and democratic state. For example, Prime Minister Emmanuel Macron stated: La République est ce lieu magique et unique qui permet à des gens de viure dans l'intensité de leur religion. C'est pour ça que je dénonce les considérations qui demandent à des citoyens d'être "discrets." Et qu'on demande à des gens d'être des musulmans modérés (The republic is a magical and unique place, wherein people may live with and within their religion. This is why I disapprove of views that require people to be 'discreet').

This description of the French republic as a 'magical and unique place' highlights that, in Macron's view, France is not 'opposed' to Islam (or, indeed, any religion), but rather to the radical Islam practiced by jihadis and Daesh. According to Macron, secularism allows individuals to study their religion individually, even as they follow the laws and regulations of the French Republic. All persons living in France must understand secularism as part of French national identity; in other words, secularism is the foundation of religious freedom. All religious identities-Christian,

\footnotetext{
${ }^{20}$ Hervé Vieillard-Baron, "L'islam en France : dynamiques, fragmentation et perspectives," L'Information geographique, Vol. 80, no. 1 (2016), 22-53.
} 
Catholic, Islamic, and atheist-are French identities. This statement, thus, appears to have been intended to convince the French people (particularly non-Muslim political leaders) that religious and cultural pluralism are integral parts of French society; at the same time, it is important for all religious practices to be conducted in accordance with French laws and regulations.

\section{Respecting diversity}

Cultural pluralism, as marked by diversity in cultural and religious practice, is not a portend of the downfall of the French Republic, but rather a strengthening of the liberal values disseminated through globalization. In the current era of globalization, questions of citizenship and civics must be re-examined to create a democratic society that respects difference. Regarding the religion of his teammate Paul Pogba, the French soccer player Antoine Griezmann stated: Quant à l'Islam, c'est une religion qui l'intéresse. Lorsque je toque à la porte de Paul Pogba et qu'il ne répond pas, je sais qu'il fait sa prière; alors, je repars et le laisse tranquille. J'aime l'observer, comparer nos pratiques religieuses respectives m'intéresse. Je suis respectueux des rites de chacun. Lorsque nous recevons pour un barbecue à la maison, je veille à choisir la bonne viande quand je sais que nous attendons des musulmans. Je me nourris de toutes les croyances. Je le dis à nouveau. L'Islam est une belle religion, il s'agit de paix, il s'agit de s'aider les uns les autres ('Islam, it is an interesting religion. When I knock on Paul Pogba's door and he doesn't answer, I know that he is praying, and so I go and let him be. I like to observe it, to compare our religious practices. I respect individuals' religious rituals. When we have a barbecue at home, I make sure I order the right (halal) meat when I have a Muslim guest. I respect all faiths. Again, I must say that Islam is a beautiful religion, one of peace, one of helping others. Through this article, titled «Antoine Griezmann s'intéresse à l'Islam » ('Antoine 
Griezmann interested in Islam'), the French website Public.fr forefronts a hybrid discourse of religion and culture. This interview with Griezmann regarding his relationship with Paul Pogba, a French soccer player and a Muslim, underscores Griezmann's view that religious practices are personal matters, and that tolerance and mutual respect should be maintained in French society.

\section{Islam in France: different from Islam elsewhere}

The practice of Islam in France has become known as 'Islam de France' (the Islam of France). 'Islam de France' is identified to be closely affiliated with different streams and schools, such as with Islam in Morocco and Saudi Arabia ${ }^{21}$. This phrase has been used by numerous French leaders to distinguish the Islam practiced in France with the Islam embraced by first-generation migrants. French leaders have identified secondgeneration immigrants and their descendants as practicing an increasingly Europeanized form of Islam, as they view themselves as members of European society ${ }^{22}$. As stated in Marianne by François Bayrou, a member of the Democratic Movement: "C'est vrai que l'islam, depuis son origine, est une religion totalisante. C'est une religion qui ne fait pas la différence entre la loi religieuse et la loi civile. Mais l'immense majorité des musulmans de France fait parfaitement la différence! Je suis à l'origine de la circulaire sur le voile islamique à l'école. Beaucoup d'hommes politiques se réfugient dans la contrainte et ils se trompent. Si nous voulons inspirer le respect de notre civilisation, cela se fera par l'entrainement» (It is true that, in its original form, Islam is a totalitarian religion, one that does not distinguish between religious and civil law.

\footnotetext{
${ }^{21}$ Naomi Davidson, Only Muslim: Embodying Islam in Twentieth-Century France, Ithaca: Cornell University Press, 2012; Charles Forsdick, "Postcolonial Counterpoint: Orientalism, France and the Maghreb by Farid Laroussi”, University of Toronto Quarterly, Vol. 87, no. 3 (2018), 320-21.

${ }^{22}$ Olivier Roy and Samir Amghar, "L’islam de France", Confluences Mediterranee N57, no. 2 (2006), 49-55.
} 
However, most Muslims in France are truly different. I am one of those who spearheaded the veiling law; many politicians try to hide from this law, and this is a mistake. If we are to respect our diversity, we require practice).

François Bayrou's statement above underscores the belief that the Islam practiced in France differs significantly from the Islam practiced elsewhere. This discourse, however, implicitly involves a process of othering, wherein the Islam practiced in France is identified as 'better' than other forms of Islam because it is moderate and secularized. It must be noted that France has changed significantly since the 1990s, when socialist parties attempted to ameliorate their ties with the growing Muslim community, and even to accommodate the community's needs (such as by establishing the CFCM in 2002-2003). These parties had promoted the integration of the Muslim community, seeking to transform Islam en France ('Islam in France') into Islam de France ('Islam of France') ${ }^{23}$.

From the discussion above, it is evident that the hybrid discourses advanced by non-Muslims who deem themselves 'defenders of secularism' have tended to emphasize the French values of tolerance and diversity. These narratives have emphasized the processes through which the French people can include the country's Muslim minority, thereby positioning them as 'active subjects' who must embrace Muslim minorities (framed as 'passive objects'). The following section will discuss a corollary: the hybrid discourses of Muslims, as presented in French media.

\section{The hybrid narratives of Muslims in France}

Coding indicates that the hybrid narratives of Muslims in France (at 0.97\%) are far in number than those of non-Muslims. The majority of Muslim narratives are conservative, emphasizing Islamic values and rejecting

\footnotetext{
${ }^{23}$ Samuel Pruvot, "François Bayrou : 'Il y a une peur de l'islam comme religion totalisante"', Marianne, April 5, 2017.
} 
integration into French society (3.29\%). Such narratives have rejected the dynamics of secularization, exploited ongoing difficulties with integration, and dismissed women's emancipation and gay rights. Nonetheless, the reality depicted by these narratives differs somewhat from the everyday experiences of the French people. French Muslims have shown a significant capacity for adaptation, being unwilling to bow to the demands of their elders and choosing instead to follow the laws of the French Republic ${ }^{24}$. This highlights French Muslims' ability to embrace new identities and to adapt their practices and beliefs to their everyday experiences in Europe ${ }^{25}$. The hybrid narratives of Muslims in France, as published in the mass media, are discussed below.

\section{The Muslim Community Must Oppose Radical Islam}

According to Jean Baubérot ${ }^{26}$, numerous sociological studies have shown that the Muslims of France have sought to integrate themselves in French society. They have sought to overcome various social and cultural challenges, striving to educate themselves and create a French Islamic identity. However, this process has not been a simple one; indeed, contradictions have been common. The government, thus, has sought to facilitate the integration of the Muslim minority into French society and the Muslim community's efforts to eradicate radicalism and jihadism (rather than challenge secularism).

Macron's statement, as cited above, received several responses from Muslim leaders. For instance, Abdelali Mamoun-an imam who published

\footnotetext{
${ }^{24}$ Abderrahim Lamchichi, "Musulmans de France, politique de reconnaissance et éthique de responsabilité", Confluences Mediterranee N57, no. 2 (2006), 25-47.

${ }^{25}$ Syamsul Arifin et. al., "Minority Muslims and Freedom of Religion: Learning from Australian Muslims' Experiences," Indonesian Journal of Islam and Muslim Societies, Vol. 9, no. 2 (2019), 295-326; Lamchichi, "Musulmans de France...

${ }^{26}$ Jean Baubérot, "La laïcité française : républicaine, indivisible, démocratique et sociale," Cites $n^{\circ}$ 52, no. 4 (2012), 11-20.
} 
« L'Islam contre radicalism » (Islam against Radicalism’) stated:

Tout d'abord, il faut préciser que la majorité écrasante des musulmans en France aspirent à vivre en paix, à vivre leur foi sereinement, sans qu'elle ne se trouve en contradiction avec leur devoir de citoyen. Mais cette communauté musulmane se sent-elle redevable vis-à-vis de la République d'agir pour combattre l'islam radical? Certains pensent qu'ils doivent agir quand d'autres pensent que ce n'est pas notre rôle, que c'est celui d'une élite, d'un encadrement musulman de faire ce travail. Notamment que c'est le travail des imams qui exercent leur fonction au sein des mosquées légales ouvertes dans l'espace républicain

('First of all, we must note that the majority of Muslims in France desire to live in peace, to practice their faith without issue, without disturbing their obligations as citizens. But, does the French community have a debt of honor to the republic for its efforts to eradicate radical Islam? Some believe that they must take action, while others believe that it is none of their business, that it is the Muslim elites and leaders who must oppose radicalism. More specifically, that it is the duty of the country's imams, those entrusted with the Republic's mosques').

Abdelali Mamoun's views were published in the magazine BFMTV shortly after the French government held a seminar to instill French values in the country's Muslim leaders. Such seminars have been controversial. On the one hand, the French government perceives imams as agents capable of emphasizing religious norms and beliefs that promote the integration of Muslims in French society. At the same time, however, some Muslim leaders have argued that the eradication of radicalism is not the responsibility of the country's imams, but rather reflects deep-rooted issues with the French education system ${ }^{27}$. In response to such views, Abdelali Mamoun stated that imams must be involved in the eradication of radicalism, as they are the ones entrusted with answering theological

\footnotetext{
${ }^{27}$ Romain Sèze, "Leaders musulmans et fabrication d'un 'islam civil' ", Confluences Mediterranee $\mathrm{N}^{\circ}$ 95, no. 4 (2015), 43-58.
} 
questions and interpreting the Qur'an. His narrative, thus, emphasizes that France's Muslims are not radical ones; Muslims must work together to ensure the social and political acceptance of Islam. At the same time, this narrative distinguishes between Muslims' political and religious identities.

\section{Reform}

The spread of radicalism among young Muslims in France has resulted in significant social anxiety. According to a survey by the Montaigne Institute, $28 \%$ of Muslims viewed Islamic values as more important than Republican ones. In response, Hakim El Karoui-a political advisor and the author of «Islam est une religion française " ('Islam is a French Religion')-proposed reform as a means of bridging Muslims and nonMuslims and as separating them from 'all others,' i.e. Frères musulmans égyptiens et européens 'Muslim brethren in Egypt and Europe', wahhabisme saoudien 'Saudi wahhabism', and turco-islamisme 'Turkish Islamism'.

In Le Figaro, Hakim El Karoui stated:

L'islam est la première religion pratiquée de France, et les musulmans constituent $8 \%$ de la population. Les musulmans sont français pour les trois quarts d'entre eux, et la moitié sont nés en France. Mais l'organisation de l'islam en France est aujourd'hui laissée à des puissances étrangères: c'est totalement inefficace, et c'est surtout scandaleux. Il faut rompre avec l'idée que l'islam est une religion étrangère, d'étrangers, avec des problèmes d'étrangers gérés par des étranger

('Islam is one of France's premiere religions, and Muslims represent $8 \%$ of the country's population. Three quarters of them are Muslim, and half of those were born in France. However, French Islamic organizations have been surrendered to foreign forces; this is not only shameful, but entirely ineffective. We must eradicate the view that Islam is a foreign religion, from a foreign land, with foreign problems caused by foreign people'. 
El Karoui thus proposed reforming Islam. For this, he supported the establishment of a 'Muslim Association for Islam in France' (Association musulmane pour l'islam de France, AMIF), one which would ensure French Muslims' control of the practice of Islam in the country. This AMIF would be an independent and neutral organization, one responsible for teaching an Islam that reflects the values of the French Republic. However, El Karoui's proposal was opposed by many, especially those who view Islam as beyond reform.

\section{Islam as part of the national community}

As with non-Muslims, many of the Muslim members of the Bureau of the Islamic Foundation in France (Bureau de la Fondation de l'Islam de France) have urged Muslims to integrate themselves into the French national community. For instance, according to the physicist and religious scholar Ghaleb Bencheikh, Il n'y a qu'une seule communauté nationale et elle ne doit pas avoir honte de sa composante musulmane. Le mot «islam» fait problème aujourd'hui, si on l'élude, ce n'est pas sérieux ('There is only one national community, and this community must recognize its Muslim components. The word 'Islam' has been seen as problematic, and the issue has not been examined seriously').

The founder of the Islamic Foundation in France, Jean-Pierre Chevènement, similarly expressed: J'ai suivi avec attention et médité les efforts de plusieurs de mes prédécesseurs pour intégrer l'islam dans la communauté nationale, J'ai le même objectif: aider à l'affirmation d'un islam français. Il faut créer les conditions pour que les musulmans de France se sentent intégrés à la communauté nationale ('I have followed, with the utmost interest and contemplation, the efforts of my predecessors to integrate Islam into the national community. I share their goal: to help buttress a French Islam. This is necessary to ensure that Muslims in France feel integrated into the national community'). 
From these statements, it may be concluded that Muslim leaders in France have sought to integrate Muslims into the country's national and political community. The government has undertaken several institutional efforts to regulate worship and other religious practices as a means of cultivating peace and harmony. However, government efforts have followed a secular humanist framework, one that recognizes religious freedoms while still emphasizing public order ${ }^{28}$.

\section{Muslims in France must respect French law}

In French law, private and public worship are protected as part of the freedom of religion. Pursuant to Article 10 of the Declaration of Human and Civil Rights (la Déclaration des droits de l'homme et du citoyen, 1879), all peoples of France have the freedom to express themselves and their opinions, including in matters of religion, so long as this does not disrupt the public order. Furthermore, pursuant to Article 1 of the Law on the Separation of Church and State (la loi de separation des Églises et de l'État), passed on December 9, 1905, the French Republic guarantees the freedom of worship; this principle is reaffirmed in Article 1 of the 1958 Constitution, which states that all individuals have equal rights before the law, irrespective of their race, religion, or country of origin. Through the European Convention on Human Rights (la convention éuropéenne des droits de l'homme, 1974), France again emphasized its dedication to protecting religious rights. However, this freedom is restricted by Paragraph 2 of Article 9, which states that freedom must be exercised within the constraints provided by law, as only then can the public order and the freedoms of others be guaranteed.

From the above-mentioned legal framework, it is evident that France has provided legal mechanisms for protecting Muslims' freedom of worship,

${ }^{28}$ Pierre-Henri Prélot, "Les tentatives d'organisation... 
including prayer and fasting, while simultaneously restricting said worship. Where Muslims desire to worship in public, they must ensure that it does not disrupt the public order ${ }^{29}$. Several Muslim leaders have recognized this restriction. As stated by Iqbal Ingar, the president of the Great Mosque of Saint-Denis: Il est reconnu par tous que l'islam pratiqué à La Réunion est humaniste, républicain et que l'on peut pratiquer sa foi tout en respectant les lois de la République ('It is recognized by all that the Islam practiced in Reunion is a humanist Islam, one based on the values of the republic, and individuals' practices must respect the laws of the Republic'). This statement implies that French Muslims acknowledge that they live in a secular land, and as such their worship practices must reflect the laws of the Republic.

From these narratives, it can be seen that several Muslim leaders in France have expressed a desire to improve integration in the national community. In the mass media, they have espoused the need to respect others, to recognize cultural and religious diversity, to obey French law, and to reject radical Islam. In this, they have not only spoken as individuals, but also as representatives of the Islamic institutions and organizations in France.

\section{Conclusion}

To ensure interfaith harmony in France, it is necessary for Muslims and non-Muslims to recognize the importance of diversity and to respect and abide by French ethics and social norms. French law distinguishes between religion and politics, and pursuant to the value of laicite the government must act neutrally in religious affairs; as a consequence, freedom of religion and respect for pluralism must be guaranteed. In this framework, it is possible for Muslims and non-Muslims to reconcile and to respect their

\footnotetext{
${ }^{29}$ Stéphane Papi, "Normes islamiques et droit interne en France : de quelques zones de confluences," Droit et societe n 88, no. 3 (2014), 689-708.
} 
differences, thereby realizing equality through neutrality.

These values, equality and neutrality, are evident in the hybrid discourses voiced by both non-Muslims and Muslims. The former discourses have emphasized religious freedom, compliance with French law, respect for difference, and recognition of French Islam as distinct from Islam elsewhere. The latter discourses, meanwhile, have emphasized the need for Muslims to oppose radical Islam, to reform Islamic practice, to integrate into the national community, and to respect and obey French law.

These discourses are indicative of a mutual positioning. French nonMuslims have sought to open themselves to diversity in religious practice, which they recognize as an inexorable consequence of increased global migration. Openness, they argue, is necessary to ensure that religious freedom and pluralism is recognized and protected. At the same time, however, these discourses perpetrate the Othering of Muslims, even as they seek to include them in the national 'Self.' This can be seen, for instance, in the government's requirement that all Muslims adhere to the secular principles that limit their public worship. At the same time, France's non-Muslim elites have asserted that the Islam in France is an Islam that recognizes the values of the French Republic, and is thus distinct from the Islam practiced elsewhere.

Meanwhile, the hybrid narratives of French Muslims are indicative of a desire to integrate themselves into French society. This is marked, for instance, by their emphasis on incorporating Islamic values into national society and their recognition of the need to obey French law. Interestingly, in their narratives, French Muslims have sought to distinguish themselves from other Muslims-particularly radical ones. In other words, they have discursively positioned other Muslims as 'the Other,' distinguishing themselves through their particular views of Islam as well as their adherence to French law. 
From these discourses, it may be seen that diverse subjects have narrated their particular conceptualizations and idealizations (of secularism, pluralism, and Islam) in accordance with their own ideologies. Said ideologies are rooted in a shared knowledge as well as mutual activities. This analysis has shown that, even though France has officially separated Church and State since 1905, hybrid narratives have emerged; they seek to reconcile secularism with religious pluralism. This has been particularly prominent amongst the younger generations, who have internalized both concepts, applied them in their everyday lives, and voiced their hybrid narratives in the mass media. It is hoped that, through such hybrid narratives, the Muslims and non-Muslims of France can realize a society wherein tolerance and harmony abound.

\section{Bibliography}

Abdeslam, Abderrahim Ait, "The Representation of Islam and Muslims in French Print Media Discourse: Le Monde and Le Figaro as Case Studies", Journal of Muslim Minority Affairs, Vol. 39, no. 4 (2019): 569-81. https://doi.org/ 10.1080/13602004.2019.1688514.

Ahyar, Muzayyin, and Alfitri Alfitri. "Aksi Bela Islam: Islamic Clicktivism and the New Authority of Religious Propaganda in the Millennial Age in Indonesia." Indonesian Journal of Islam and Muslim Societies 9, no. 1 (May 24, 2019): 1-29. https://doi.org/10.18326/ijims.v9i1.1-29.

Akmaliah, Wahyudi. "The Demise of Moderate Islam: New Media, Contestation, and Reclaiming Religious Authorities." Indonesian Journal of Islam and Muslim Societies 10, no. 1 (May 29, 2020): 1-24. https://doi.org/10.18326/ijims. v10i1.1-24.

Allen, Christopher. Islamophobia. Burlington: Ashgate, 2010.

Arifin, Syamsul, Hasnan Bachtiar, Ahmad Nur Fuad, Tongat Tongat, and Wahyudi Wahyudi, "Minority Muslims and Freedom of Religion: Learning from Australian Muslims' Experiences”, Indonesian Journal of Islam and Muslim Societies, Vol. 9, no. 2 (2019): 295-326. https://doi.org/10.18326/ ijims.v9i2.295-326.

Baubérot, Jean, "La laïcité française : républicaine, indivisible, démocratique et sociale." Cites n 52, no. 4 (2012): 11-20. https://www.cairn.info/revue- 
Hybrid perspectives: Muslim and secular discourses in French politics (Aprillia Firmonasari, et.al)

cites-2012-4-page-11.htm.

Davidson, Naomi. Only Muslim: Embodying Islam in Twentieth-Century France. Ithaca: Cornell University Press, 2012.

Djohar, Hasnul Insani, "Folktales and Rites of Passage in Randa Jarrar's A Map of Home”, Poetika : Jurnal Ilmu Sastra, Vol. 7, no. 2 (2019): 148-57. https:// doi.org/10.22146/poetika.v7i2.51160.

Evolvi, Giulia, "Hybrid Muslim Identities in Digital Space: The Italian Blog Yalla”, Social Compass, Vol. 64, no. 2 (2017): 220-32. https://doi. org/10.1177/0037768617697911.

Firmonasari, Aprilia, Wening Udasmoro, and Yohanes Tri Mastoyo, "Understanding Secularism and National Identity in French Political Discourses”, Humaniora, Vol. 32, no. 2 (2020): 135-50. https://doi. org/10.22146/jh.55450.

Forsdick, Charles, "Postcolonial Counterpoint: Orientalism, France and the Maghreb by Farid Laroussi”, University of Toronto Quarterly, Vol. 87, no. 3 (2018): 320-21. https://doi.org/10.3138/utq.87.3.29.

Fredette, Jennifer. Constructing Muslims in France - Discourse, Public Identity, and the Politics of Citizenship. Philadelphia: Temple University Press, 2014. https:// doi.org/10.26530/OAPEN_469365.

Geisser, Vincent, "L'islamophobie En France Au Regard Du Débat Européen", in Musulmans de France et d'Europe, Rémy Leveau and Khadija Mohsen-Finan (eds.). Connaissance Du Monde Arabe, Paris: CNRS Éditions, 2013: 59-79. http://books.openedition.org/editionscnrs/2871.

Kusumaningrum, Ayu Fitri, "Krisis Identitas Dalam Cerpen A Pair of Jeans Karya Qaisra Shahraz", Poetika: Jurnal Ilmu Sastra, Vol. 7, no. 1 (2019): 51-62. https://doi.org/10.22146/poetika.v7i1.43500.

Lamchichi, Abderrahim, "Musulmans de France, politique de reconnaissance et éthique de responsabilité”, Confluences Mediterranee N57, no. 2 (2006): 25-47. https://www.cairn.info/revue-confluences-mediterranee-2006-2page-25.htm?ref=doi.

McDougall, James, "Laïcité, Sociologie et Histoire Contemporaine de l'islam", Annales, Histoire, Sciences Sociales, Vol. 73, no. 2 (2018): 411-39. https:// doi.org/10.1017/ahss.2019.6.

Moyou, E., "Possibilité de débats sereins sur l'immigration selon les Français 2018."

Statista, November 1, 2019. https://fr.statista.com/statistiques/955065/ debattre-sereinement-immigration-france/.

Papi, Stéphane, "Normes islamiques et droit interne en France : de quelques zones 
de confluences", Droit et societe n ${ }^{\circ} 88$, no. 3 (2014): 689-708. https://www. cairn.info/revue-droit-et-societe1-2014-3-page-689.htm?ref=doi.

Portier, Philippe, "The Substantivist Turn of French Laicism", Horizontes Antropológicos, Vol. 24, no. 52 (2018): 21-40. https://doi.org/10.1590/ s0104-71832018000300002.

Prélot, Pierre-Henri, "Les tentatives d'organisation du culte musulman en France au prisme du principe de laïcité", Revue du droit des religions, no. 6 (2018): 13-26. https://doi.org/10.4000/rdr.324.

Pruvot, Samuel, "François Bayrou : 'Il y a une peur de l'islam comme religion totalisante", Marianne, April 5, 2017.

Putri, Rizqi Auliawati, "Dekonstruksi Girl Power dalam Novel The Devil Wears Prada Karya Lauren Weisberger”, Poetika : Jurnal Ilmu Sastra, Vol. 8, no. 1 (2020): 51-63. https://doi.org/10.22146/poetika.v8i1.56540.

Rodina, Katarina A., "Vygotsky`s Social Constructionist View on Disability: A Methodology for Inclusive Education", in Enabling Lifelong Learning in Education, Training and Development: European Learning Styles Information Network (ELSIN). Oslo CD/ISDN: University of Oslo, 2006. http://lchc. ucsd.edu/mca/Paper/VygotskyDisabilityEJSNE2007.pdf.

Roy, Olivier, and Samir Amghar. "L'islam de France." Confluences Mediterranee №57, no. 2 (2006): 49-55. https://www.cairn.info/revue-confluencesmediterranee-2006-2-page-49.htm?ref=doi.

Sèze, Romain, "Leaders musulmans et fabrication d'un 'islam civil”", Confluences Mediterranee $\mathrm{N}^{\circ}$ 95, no. 4 (2015): 43-58. https://www.cairn.info/revueconfluences-mediterranee-2015-4-page-43.htm?ref=doi.

Udasmoro, Wening, "Discourse Subaltern Dalam Masyarakat Interkultural: Mencermati Relasi Gender Jilbab dan Perempuan Berjilbab Di Prancis", Jurnal Ilmu Sosial dan Ilmu Politik, Vol. 14, no. 1 (2010): 1-22. https://doi. org/10.22146/jsp.10946.

Udasmoro, Wening, "The Language Construction of Muslims as The Others in French Contemporary Discourses", Indonesian Journal of Islam and Muslim Societies, Vol. 7, no. 1 (2017): 77-99. https://doi.org/10.18326/ijims. v7i1.77-99.

Vieillard-Baron, Hervé, "L'islam en France : dynamiques, fragmentation et perspectives”, L'Information geographique, Vol. 80, no. 1 (2016): 22-53. https://www.cairn.info/revue-l-information-geographique-2016-1-page-22. htm. 
Hybrid perspectives: Muslim and secular discourses in French politics (Aprillia Firmonasari, et.al)

Vygotsky, L. S., "Interaction between Learning and Development", in Mind in Society: Development of Higher Psychological Processes. Cambridge: Harvard University Press, 1978: 79-91. doi:10.2307/j.ctvjf9vz4.11.

Vygotsky, L. S. Mind in Society: Development of Higher Psychological Processes. Cambridge: Harvard University Press, 1978. https://doi.org/10.2307/j. ctvjf9vz4.

Willaime, Jean-Paul, "Religious and Secular France Between Northern and Southern Europe", Social Compass, Vol. 45, no. 1 (1998): 155-74. https:// doi.org/10.1177/003776898045001013. 
